\title{
光遮断法を用いた気体燃料噴射弁の噴射率計測*
}

\author{
荒木 幹也*1, 藤原 康 裕*2, 志賀 聖一*1 \\ 中 村 壽 雄*3, 小保方 富夫*4
}

\section{Injection Rate Measurement of a Gaseous Fuel Injector Using a Beam Cut Method}

\author{
Mikiya ARAKI ${ }^{* 5}$, Yasuhiro FUJIWARA, Seiichi SHIGA, \\ Hisao NAKAMURA and Tomio OBOKATA \\ ${ }^{* 5}$ Department of Mechanical Engineering, Gunma University, \\ 1-5-1 Tenjin-cho, Kiryu-shi, Gunma, 376-8515 Japan
}

\begin{abstract}
Injection rate of a gaseous fuel injector was calculated by measuring the needle valve lift history. In our lab, a gaseous fuel injection rate meter using 1-dimensional pipe flow was developed. In the present study, the measurement accuracy of the injection rate meter was examined by comparing the theoretical injection rate estimated from the needle valve lift history. The needle valve lift was measured using an optical method. A small beam cut plate is attached to the needle valve of the gaseous fuel injector. A laser beam passes through the beam cut plate, and the variation of the beam intensity was measured with a photo sensor. From the beam intensity, the needle valve lift history was estimated. One-dimensional, compressible, inviscid, adiabatic flow was assumed, and the instantaneous mass flow rate through the needle valve sheet, the injector sack, and the injection hole was estimated. The estimated injection rate was compared with that obtained with the gaseous fuel injection rate meter. The estimated and measured injection rates agree relatively well even at transient duration. It is shown that the injection rate meter has high reliability and accuracy.
\end{abstract}

Key Words: Injection Rate, Gaseous Fuel Injector, Compressibility, Automotive Engines

\section{記 号 表}

$$
\begin{array}{lll}
A & : & \text { 断面積 } \\
C d & : \text { 流量係数 } \\
m & : \text { 質量 } \\
\dot{m} & : \text { 質量流量 } \\
P & : \text { 圧力 } \\
P_{r j} & : \text { 噴射圧力 (全圧) } \\
R & : \text { 気体定数 } \\
T & : \text { 静温 } \\
t & : \text { 時刻 } \\
u & : \text { 速度 } \\
V & : \text { 体積 } \\
\gamma & : \text { 比熱比 }
\end{array}
$$

* 原稿受付 2007 年 7 月 11 日.

*1 正員, 群馬大学大学院工学研究科(忍376-8515 桐生市天神 町 1-5-1).

*2 群馬大学大学院工学研究科修士課程学生

*3 群馬大学大学院工学研究科.

*4 正員, フェロー, 群馬大学大学院工学研究科.

E-mail : araki@me.gunma-u.ac.jp

$$
\begin{array}{lll}
\rho & : & \text { 密度 } \\
\tau & : & \text { 噴射期間 }
\end{array}
$$

\section{1. 緒言}

気体燃料を，自動車用燃料として適用する動きが進 みつつある. 圧縮天然ガス (CNG: Compressed natural gas）や水素は, Tank to wheel ベースの二酸化炭素排 出量を削減できるため，大きな期待が寄せられている. 吸気管噴射火花点火機関 ${ }^{(1)}$ ，筒内直接噴射火花点火 機関 (2)，筒内直接噴射圧縮点火機関 (3) など，多岐に わたる機関について，気体燃料の適用可能性が検討さ れている.

気体燃料は，従来の液体燃料と同様に燃料噴射弁か ら供給される. 燃料噴射弁の噴射率（単位時間当たり の燃料噴射量）は機関性能に大きな影響を及ぼすため, 重要な設計要素となる. 液体燃料の噴射率計側法とし ては，噴射された燃料を一定断面積の管内に導き，一 次元流れを仮定することで計測を行う「ボッシュ式然 
料噴射率計」4が，広く知られている。しかしなが ら, ボッシュ式燃料噴射率計に気体燃料をそのまま適 用した場合，計測は不可能となる。

著者らは，ボッシュ式然料噴射率計と同様に，一 次元流れを作りその静圧変動から気体然料噴射弁の噴 射率を求める手法 $\left.{ }^{5} 6\right)$ を提案してきた。これまでに, 誤差 $2 \sim 3 \%$ 以内での計測が可能であることが示され (6)，実用レベルに近づきつつある。これまでのとこ ろ，気体燃料噴射率計で計測した噴射率を積分して噴 射 1 回当たりの質量流量を求め, 一方, 真空容器への 繰り返し噴射から噴射 1 回あたりの質量流量を求め, 両者の比較を行うことで計測精度の検証を行っている $\left.{ }^{(5}, 6\right)$ 。しかしながらこの検証法では，噴射弁の開 弁・閉弁過渡期間における噴射率の急激な変化が，正 確に計測されているかどうかの判断が難しい.

本研究では，著者らが提案してきた気体然料噴射率 計 $\left.\begin{array}{ll}5 & 6\end{array}\right)$ の，開弁・閉弁過渡期間における計測精度の 検証を行う。噴射弁の開弁・閉弁過渡期間における噴 射率の時間変化を，半実験的に算出することを試みる. 噴射弁針弁の揚程時間变化を直接計測することで針弁 シート部断面積の時間変化を求め, その前後の圧力か ら理論流量を算出する. こうして算出された理論噴射 率と, 気体燃料噴射率計 ${ }^{5} 6$ 6 の計測結果との比較を 行い, 気体燃料噴射率計の計測精度を検証する.

\section{2. 実験装置および方法}

$2 \cdot 1$ 針弁揚程計測 図 1 に, 気体然料噴射弁 および針弁に取り付けられた遮光板概略を示寸. 本研 究では供試噴射弁として, 市販 NGV (Natural gas vehicle）の, 吸気管噴射用燃料噴射弁（KEIHIN, 06164PDNJ00）を用いた。

図 1 (a)，(b) はそれぞれ，閉弁時，開弁時の断 面図を示寸。噴射弁筐体内部に，円筒状の針弁（供試 噴射弁の針弁は，いわゆる「針形状」をしていないが， 通例に従い針弁と呼ぶ）が設置されている. 気体然料 は，針弁内部を通って供給され，その側面に空けられ た穴から外部へと導かれる. ソレノイドにより針弁が 引き上げられることで，シート部隙間から気体然料が 流出し，サックを経て噴口から噴出する. 針弁先端部 には，気体燃料のリークを防ぐためゴムシートが貼り 付けられている ${ }^{(1)}$ 。噴射并噴口径は， $\phi 2 \mathrm{~mm}$ であ る. 噴射弁針弁に, 直径 $\phi 0.6 \mathrm{~mm}$ の支持棒を介して 遮光板が取り付けられる. 支持棒および庶光板は針弁 と比較して十分に軽く, 慣性質量増大による開弁・閉 弁速度の変化はほとんど無い。

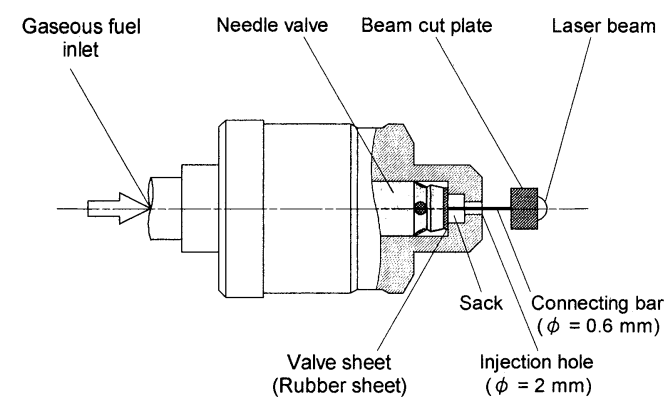

(a) Needle valve close

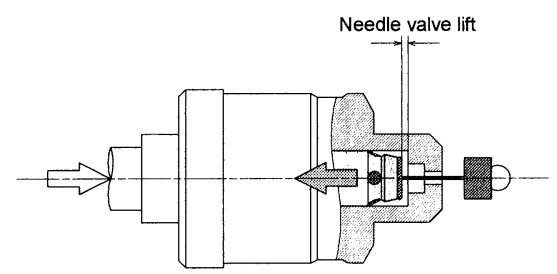

(b) Needle valve open

Fig. 1 Schematic of gaseous fuel injector and beam cut plate attached to needle valve.

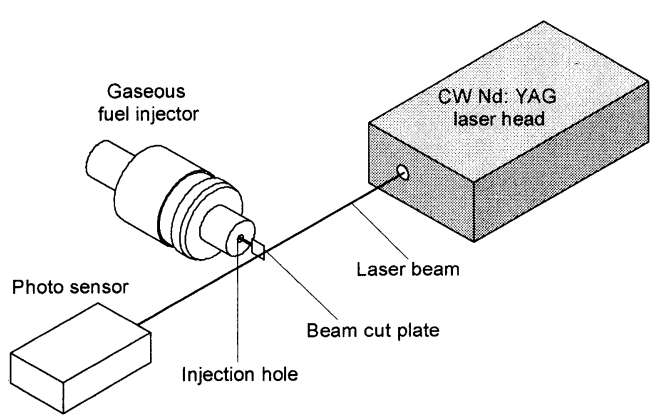

Fig. 2 Optics for needle valve lift measurement using beam cut method.

供試気体に窒素を用いた。気体は，ボンべから供給 される.ボンベからの気体は，レギュレータにより調 圧されバッファ室に導かれる. 配管内の圧力胍動を抑 えるため, バッファ室を設置した。 バッファ室からの 気体は，気体燃料噴射并に導かれる。燃料噴射圧 $P_{i z}$ は, 絶対圧で $356 \mathrm{kPa}$ (ゲージ圧で $255 \mathrm{kPa}$ ) である. 以後, 圧力は全て絶対圧で標記する. ファンクション ジェネレータにより方形波を発生し, 開弁・閉弁信号 とする. 開弁・閉弁信号は, 噴射弁駆動回路に送られ る. 
図 2 に，光遮断法を用いた針弁揚程計測光学系を 示す. 光源に, 連続発振 Nd: YAG レーザ (Laser Export，LCS-DTL-317-50）を用いた。レーザ波長は $532 \mathrm{~nm}$ ，レーザビーム径は約 $1.5 \mathrm{~mm}$ である、レーザ ビームを，遮光板によっておよそ半分遮断する．遮断 されなかったレーザビームを, 高速フォトセンサ（浜 松ホトニクス，S3071）で受光する. 噴射弁の開弁・ 閉弁動作により，遮光板は移動する. これに伴い遮断 される光束量は変化し, フォトセンサに入射する光量 は変化する. フォトセンサに入射する光量から, 遮光 板の移動量すなわち針弁揚程を計測する. フォトセン サからの出力信号は, デジタルオシロスコープ

(ReCroy, WR6030A) で AD 変換され取得される.

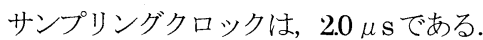

あらかじめ, 遮光板変位とフォトセンサ出力との 関係を計測した. マイクロメータを用いて遮光版を微 動し, その変位と輝度との関係の較正值を取得した. また，噴射弁に燃料供給ライン圧力が加わると，開 弁・閉弁過程に要する時間が変化することが明らかに なった.このため針弁揚程計測の際には，噴射弁に然 料供給ライン圧力を加え，実際に気体を噴射しながら 計測を行った.

$2 \cdot 2$ 理論噴射率 図 3 に, 気体燃料噴射弁内 部の流れ場の 1 次元モデルを示す，本報では，まずは 現象を単純な 1 次元流れに置き換え, 解析を試みる. 以下, 一次元, 圧縮性, 非粘性, 断熱流れを仮定し, また理想気体を仮定する.この仮定を基に，噴射弁内 部の流れをモデル化する. 気体の速度, 圧力, 静温, 密度, 質量, 質量流量, 比熱比, 気体定数を $u, P$, $\rho, T, m, \dot{m}, \gamma, R$ とおく. また断面積, 流量係 数, 体積を $A, C d, V$ とおく. 時間とともに変化する 変数の場合には，変数記号に(t)を付すこととする．な お本研究の実験条件範囲では, 温度, 圧力の変化とと もに実在気体効果により $P V / m T$ が最大で $0.2 \%$ 程度 変化すると見積もられる ${ }^{(7)}$ ，本研究ではその影響は 比較的小さいものと考え， $P V / m T=R$ で一定，すな わち理想気体を仮定することとする.

図 3 を基に, 流れ場を, 以下の領域(1)〜領域(5に 分割する.

領域(1) : 燃料供給ライン。ここでは流れは十分遅く, また圧力, 静温は一定とする. 速度, 圧力, 静温を, $u_{1}(=0 \mathrm{~m} / \mathrm{s}), P_{1}(=356 \mathrm{kPa})$, $T_{1}(=293 \mathrm{~K})$ とおく.

領域(2) : 針弁シート. シート断面積は針弁揚程の変 化とともに変化する. 速度, 密度, 断面積, 流量係数走, $u_{2}(t), \rho_{2}(t), A_{2}(t), C_{2}$, ,

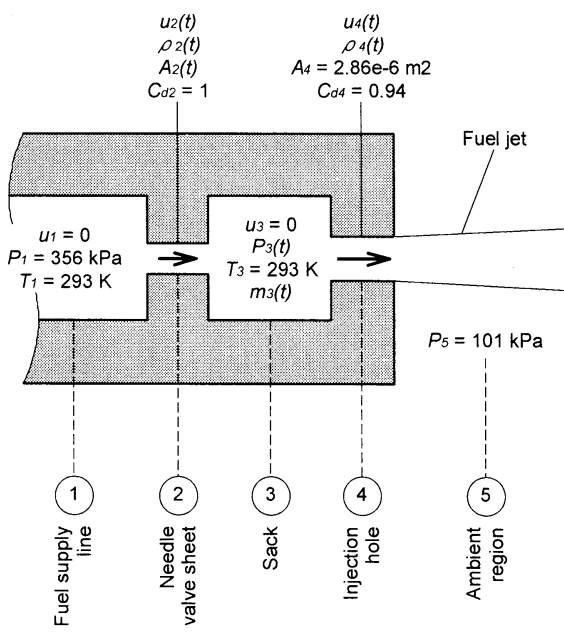

Fig. 3 One-dimensional model of flow field inside gaseous fuel injector.

Table 1 Initial conditions

\begin{tabular}{|l|l|}
\hline$A_{2}(O)$ & $0 \mathrm{~m}^{2}$ \\
\hline$u_{2}(0)$ & $0 \mathrm{~m} / \mathrm{s}$ \\
\hline$m_{3}(O)$ & $0.163 \mathrm{mg}$ \\
\hline$P_{3}(0)$ & $101 \mathrm{kPa}$ \\
\hline$u_{4}(0)$ & $0 \mathrm{~m} / \mathrm{s}$ \\
\hline
\end{tabular}

おく．針弁シートでの流量係数は不明であ り, 本研究では $C_{E 2}=1$ とした。供試噴射 弁の針弁は複雑な形状を有するため，針弁 揚程とともに変化するシート部での流量係 数を予想することは, 現状では困難である. 最終的には，（i）針弁揚程をある值で一 定に保ち，定常噴射を行うことで各揚程に おける流量係数を求める，あるいは（ii) CFD により解析的に流量係数を求めると いった方法が必要となると考えられる.

領域(3) : 針弁シート部と噴射弁噴口の間のサック. ここでは流れは十分遅いと仮定する。この 時, エネルギー式 ${ }^{8}$ より $T_{1}=T_{3}$ となる. 速度, 圧力, 静温, 質量を, $u_{3}(=0 \mathrm{~m} / \mathrm{s})$, $P_{3}(t), T_{3}(=293 \mathrm{~K}), m_{3}(t)$ とおく.

領域(4)：噴射弁噴口. 断面積は一定である. 速度, 密度, 断面積, 流量係数を, $u_{4}(t), \rho_{4}(t)$, $A_{t}\left(=2.86 \mathrm{e}-6 \mathrm{~m}^{2}\right) ， C_{d 4}(=0.94)$ とおく. 断面積 $A_{4}$ の值には，遮光板支持棒による 断面積减少分が考慮されている，噴射弁噴 口の流量係数 $C_{d 4}$ は，気体然料噴射率計 5 
6)を用い, 針弁全開状態て噴射を行うこと で実験的に求めた，なおこの際も，遮光板 を取り付けたまま実験を行っている.

領域(5): 噴射弁噴口下流の静止䨌囲気. 圧力を $P_{5}$ $(=101 \mathrm{kPa})$ とおく.

以上の仮定を基に，噴射弁内部を通過する気体の質量 流量を算出する.

ある時刻 $t$ に, 領域(2)を通過する気体の質量流量 $\dot{m}_{2}(t)$ は, 領域(1)と領域(3)の圧力比, および断面積 $A 2(t)$ で決まる ${ }^{(7)}$.

(i) 領域(1) と領域(3)の圧力比 $P_{3}(t) / P_{1}$ が, 臨界圧力 比 ${ }^{(7)}$ より小さい場合, 流れは閉塞し,

$$
\begin{aligned}
\dot{m}_{2}(t) & =C_{d 2} A_{2}(t) \rho_{2}(t) u_{2}(t) \\
& =\frac{A_{2}(t) P_{1}}{\sqrt{R T_{1}}} \sqrt{\gamma\left(\frac{2}{\gamma+1}\right)^{\frac{\gamma+1}{\gamma-1}}}
\end{aligned}
$$

で表される(7).

(ii) 領域(1)と領域(3)の圧力比 $P_{3}(t) / P_{1}$ が, 臨界圧力

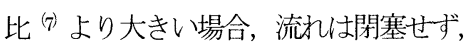

$$
\begin{aligned}
\dot{m}_{2}(t) & =C_{d 2} A_{2}(t) \rho_{2}(t) u_{2}(t) \\
& =\frac{A_{2}(t) P_{1}}{\sqrt{R T_{1}}} \sqrt{\frac{2 \gamma}{\gamma-1}\left\{\left(\frac{P_{3}(t)}{P_{1}}\right)^{\frac{2}{\gamma}}-\left(\frac{P_{3}(t)}{P_{1}}\right)^{\frac{\gamma+1}{\gamma}}\right\}}
\end{aligned}
$$

で表される(

ある時刻 $t$ に, 領域(4)を通過する気体の質量流量 $\dot{m}_{4}(t)$ は, 領域(3)と領域(5)の圧力比で決まる ${ }^{(7)}$.

(iii) 領域(3) と領域(5)の圧力比 $P_{5} / P_{3}(t)$ が, 臨界圧力 比 ${ }^{(7)}$ より小さい場合, 流机は閉塞し,

$$
\begin{aligned}
\dot{m}_{4}(t) & =C_{d 4} A_{4} \rho_{4}(t) u_{4}(t) \\
& =C_{d 4} \frac{A_{4} P_{3}(t)}{\sqrt{R T_{3}}} \sqrt{\gamma\left(\frac{2}{\gamma+1}\right)^{\frac{\gamma+1}{\gamma-1}}}
\end{aligned}
$$

で表される (7).

(iv) 領域(3)と領域(5)の圧力比 $P_{5} / P_{3}(t)$ が, 臨界圧力 比 (7)より大きい場合, 流れは閉塞せず,

$$
\dot{m}_{4}(t)=C_{d 4} A_{4} \rho_{4}(t) u_{4}(t)
$$

$$
=C_{d 4} \frac{A_{4} P_{3}(t)}{\sqrt{R T_{3}}} \sqrt{\frac{2 \gamma}{\gamma-1}\left\{\left(\frac{P_{5}}{P_{3}(t)}\right)^{\frac{2}{\gamma}}-\left(\frac{P_{5}}{P_{3}(t)}\right)^{\frac{\gamma+1}{\gamma}}\right.}
$$

で表される(け).

領域(1)および領域(5)の圧力 $P_{1}, P_{5}$ は一定であり既 知である. 領域(3)の圧力 $P_{3}(t)$ が分かれば，噴射弁内 部を通過する気体の質量流量は決まる. 微小時間 $d t$ の間に, 領域(3) 流入する気体の質量と, 領域(3)ふら 流出する気体の質量は, 以下の連続の式を満足する.

$$
m_{3}(t+d t)=m_{3}(t)+\dot{m}_{2}(t) d t-\dot{m}_{4}(t) d t
$$

ただし， $m_{3}(t)$ は領域(3の気体の質量である.また， 状態方程式より,

$$
\begin{aligned}
& P_{3}(t) V_{3}=m_{3}(t) R T_{3} \\
& P_{3}(t+d t) V_{3}=m_{3}(t+d t) R T_{3}
\end{aligned}
$$

が成立する. を代入すると,

$$
P_{3}(t+d t)=P_{3}(t) \frac{m_{3}(t)+\dot{m}_{2}(t) d t-\dot{m}_{4}(t) d t}{m_{3}(t)}
$$

が成立する. (8) 式より, 微小時間 $d t$ 後における領 域(3)の圧力 $P_{3}(t+d t)$ が求められる.

表 1 に, 計算の初期条件を示す. まず, 各変数に $t$ $=0 \mathrm{~ms}$ での初期值を代入する. (1) 式 (4) 式を 用いて, 微小時間 $d t$ の間に領域(3)流入・流出する 気体の質量流量を求める. (8) 式を用いて, 微小時 間 $d t$ 後のサック内圧力を求める. 以上を繰り返し計 算し, 気体燃料噴射弁内部の気体の質量流量の時間変 化を求める. 領域(4)を通過する気体の質量流量 $\dot{m}_{4}(t)$ が，気体燃料噴射弁の噴射率となる.

\section{3. 実験結果および考察}

3 - 1 針弁揚程計測 困 4 に, 遮光板位置とフ オトセンサ出力の関係を示す. 縦軸はフォトセンサ出 力, 横軸は遮光板位置を示す. レーザビ一ム強度はガ ウシアン分布をもつため, 遮光板の変位とフォトセン 


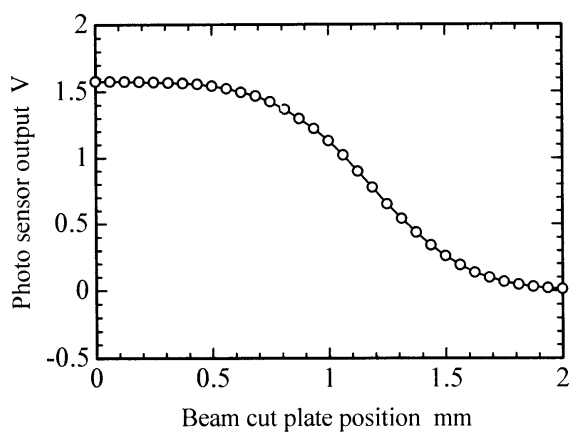

Fig. 4 Relationship between beam cut plate position and photo sensor output.

サ出力は直線関係にならない，そこで，マイクロメー 夕に遮光板を取り付け, 微動しながらフォトセンサ出 力を記録した．以下では，図40較正曲線を用いてフ オトセンサ出力を針弁揚程に換算する.

図 5 に，気体燃料噴射弁の針弁揚程およびサック圧 力 $P_{3}$ の時閒变化を示す. 図 5 (a) は, 噴射弁駆動回 路への入力電圧を示寸. 図 5 (b) は, 計測された針 并揚程を示寸. 図 5 (c) は, 針弁揚程より算出した サック圧力 $P_{3}$ を示す. 横軸は時刻 $t$ を示寸. 開弁信 号の入力時刻を横軸のゼロ点とした。噴射期間は $\tau=$ $20 \mathrm{~ms}$ である.

時刻 $t=0 \mathrm{~ms}$ において開弁信号が入力されると, 約 $2 \mathrm{~ms}$ の遅れの後に, 針弁が開弁動作を開始する. 開 弁動作に要する時間は約 $0.5 \mathrm{~ms}$ である. 針弁揚程の 増大とともにサック压力 $P_{3}$ も増大し, 針弁揚程が最 大となると同時に, サック圧力 $P_{3}$ は噴射圧力 $P_{1}(=$ $356 \mathrm{kPa})$ に達する.

時刻 $t=$ 約 $3 \mathrm{~ms}$ 以降，針弁揚程は最大となり，その 間サック圧力は噴射圧力 $P_{1}(=356 \mathrm{kPa})$ と同じ值を 保つ。

時刻 $t=20 \mathrm{~ms}$ において閉弁信号が入力されるとほ ぼ同時に，針弁が閉弁動作を開始する．閉弁動作に要 する時間は約 $1 \mathrm{~ms}$ である. 針弁着座後，特にバウン ズは見られないことが分かる. 針弁先端のゴムシート (1)により，バウンズが抑制されているものと考えら れる. 閉弁動作の開始からわずかに遅れてサック圧力 $P_{3}$ も減少を開始し，針弁揚程がゼロとなるとほぼ同 時に，サック圧力 $P_{3}$ も大気圧に启る.

光遮断法を用いることで, 高速で変位する針弁の挙 動を捉えることが可能であることが分かる. また, 単 純な一次元流孔を仮定することで, 時々刻々と変化す

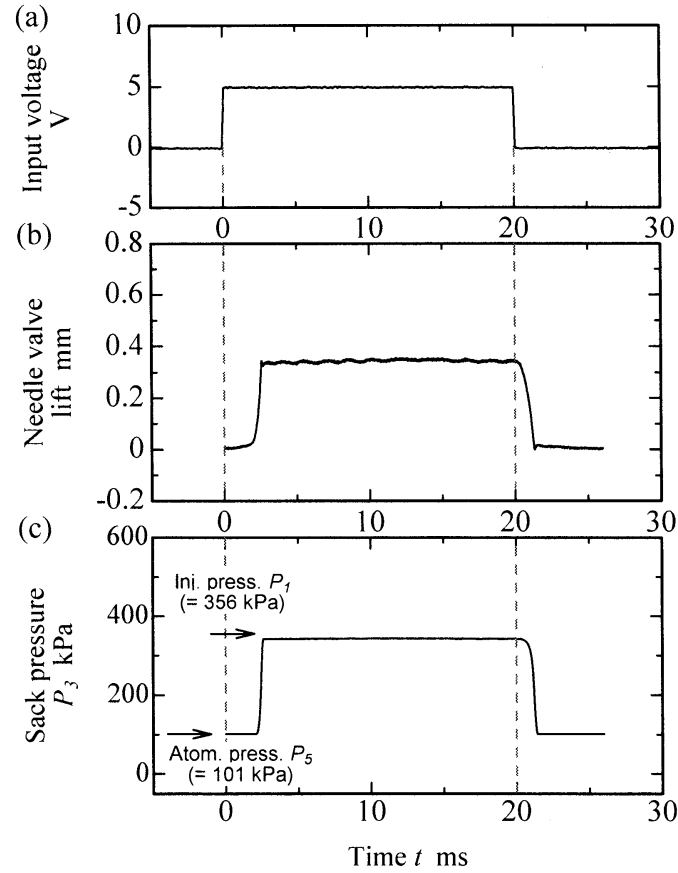

Fig. 5 Histories of needle valve lift and sack pressure of gaseous fuel injector.

るサック圧力 $P_{3}$ を見積もることができることが分か る.

3 -2 理論噴射率 図 6 に, 気体然料噴射弁の 噴射率時間変化を示寸. 図 6 (a) は, 噴射弁駆動回 路一の入力電圧を示寸. 図 6 (b) は, 針弁揚程より 算出した理論噴射率 $\dot{m}_{4}$, ならびに気体燃料噴射率計 (6) を用いて計測された噴射率を示す. 横軸は時刻 $t$ を示す. 開弁信号の入力時刻を横軸のゼロ点とした. 噴射期間は $\tau=20 \mathrm{~ms}$ である. なお気体然料噴射率計 (6)を用いる際には, (i) 遮光板による慣性質量増大 から針弁動作がわずかに遅くなる可能性があること，

（ii）遮光板支持棒のため噴口面積 $A_{4}$ が小さくなるこ とを考慮し，噴射弁に遮光板を取り付けたまま計測を 行った. また気体燃料噴射率計では, 噴射分噴口から 静圧計測点までの距離が $100 \mathrm{~mm}$ ある ${ }^{(6)}$ ため, 計測 の時間遅れを生じる. 図6では, 気体燃料噴射率計の 計測結果の横軸を, 約 $0.3 \mathrm{~ms}$ ずらして表示している.

図 6 （b）より，針弁揚程より算出した理論噴射率 と, 気体燃料噴射率計で計測した噴射率は, 比較的よ く一致することが分かる. 針弁揚程を計測し, 単純な 一次元流孔を仮定することで，噴射率の開弁・閉弁過 渡期間の噴射率の急激な変化を，ある程度正確に見積 もることができることが分かる．ただし前報で明らか 

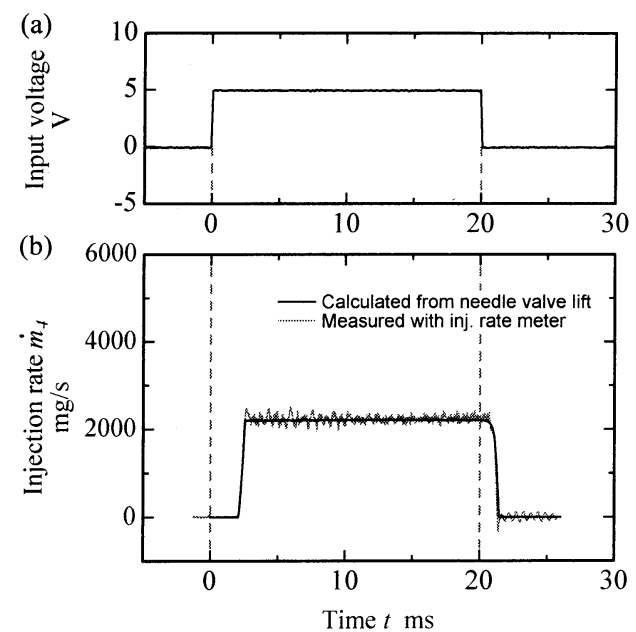

Fig. 6 Injection rate history of gaseous fuel injector.
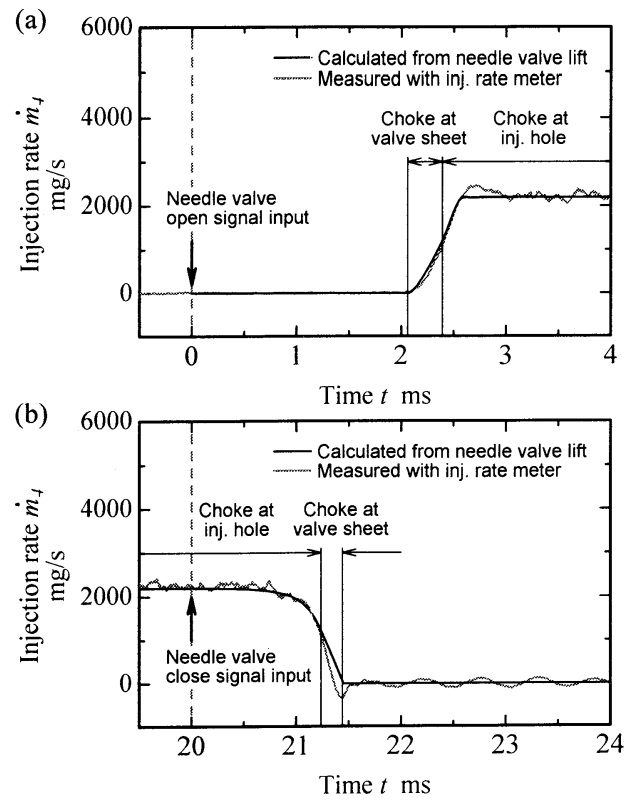

Fig. 7 Injection rate history at transient duration.

になったように，気体然料噴射率計を用いた場合，定 常噴射期間中に，流れの蛇行に伴う静圧の高周波変動 が計測される ${ }^{(6)}$ 。この結果, 噴射率計測結果にも高 周波変動が見られる ${ }^{(6)}$ 。この変動は, 噴射率の変動 に起因するものではないため除去する必要があり，今 後の大きな課題である ${ }^{8}$ と考えている.

図 7 に, 開弁・閉弁過渡期間における噴射率時間変 化を示寸. 図 7 (a) は, 開弁信号入力直後の噴射率 の時間変化を示寸. 図 7 (b) は, 閉弁信号入力直後
の噴射率の時間変化を示寸. 横軸は時刻 $t$ を示寸. $t=$ $0 \mathrm{~ms}$ で開弁信号が， $t=20 \mathrm{~ms}$ で閉弁信号が入力され る. 図 7 には，針弁シート（領域(2)），噴射弁噴口 (領域(4)）のいずれで流れの閉塞 (7)が生じているか, あわせて示す。

図 7 より，開弁・閉弁過渡期間においても，針弁揚 程より算出した理論噴射率と, 気体燃料噴射率計 (6) を用いて計測された実測噴射率は，比較的よく一致寸 ることが分かる. 気体燃料噴射率計は, 開弁・閉弁過 渡期間においても，比較的高い精度での計測が可能で あることが示唆されたと言える.

開弁・閉弁過渡期間において，針弁シ一トで流れの 閉塞が生じる条件になると，理論噴射率が気体然料噴 射率計 (6) の計測結果をやや上回る. 本研究では, 針 弁シート (領域(2) での流量係数が不明のため, その 值を 1 として定式化を進めた. 実際には，流量係数は 1 以下であり，気体燃料噴射率計 ${ }^{6}$ による実測值と のずれを生じたと考えられる.この誤差については, 光遮断法による噴射率予測の改善が必要であり, 針弁 シートでの流量倸数の把握が今後の課題である.

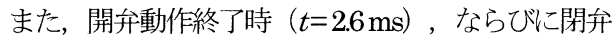
動作終了時 $(t=21.4 \mathrm{~ms})$ において, 気体燃料噴射率 計の計測結果に「オーバーシュート」，「アンダーシ ユート」が見られることが分かる，気体然料噴射并噴 口 $(d=2 \mathrm{~mm})$ と, 気体然料噴射率計の計測管内径 $(D=8 \mathrm{~mm})$ の直径差が大きい 6 ため，噴射された 気体が, 計測管内の流れ方向のみならず半径方向にも 過度に膨張することで生じる現象と推察される.この 誤差については, 気体燃料噴射率計 ${ }^{(6)}$ の改善が必要 であり，今後の大きな課題である.

これまでの研究 ${ }^{5}$. 6 ) では, 気体燃料噴射率計の計 測精度確認のため, 真空容器への繰り返し噴射を用い た較正試験を行ってきた。この手法では，噴射 1 回当 たりの平均噴射率は分かるものの, 開弁・閉弁過渡期 間における噴射率計測精度を検証することはできなか った. 本研究で提案する, 光遮断法を用いた針弁揚程 計測法，ならびに一次元流れを仮定した理論噴射率算 出法により，気体燃料噴射弁の開弁・閉弁過渡期間に おける噴射率特性の把握が，ある程度可能となった。

これにより, 従来の真空容器を用いた較正法 56 で は不明であった，気体燃料噴射率計 5.6 の改善点が 明らかになったと考えている.

\section{4. 結言}

光遮断法を用い, 気体燃料噴射弁の針弁揚程計測 を行った．計測された針弁揚程をもとに，理論噴射率 
を算出した. 算出された理論噴射率を基に，気体燃料 噴射率計の計測精度を検証した. 得られた知見を以下 に示寸.

（1）噴射弁針弁に取り付けた遮光板でレ一ザビームを 遮り，透過光強度の時間変化から針弁揚程の時間 変化を計測した。

（2）計測された針弁揚程の時間変化を元に，一次元， 圧縮性，非粘性，断熱流れを仮定することで，理 論噴射率を算出した.

（3）針弁揚程より算出された理論噴射率と，気体燃料 噴射率計で計測された実測噴射率は，比較的良い 一致を見せた。

（4）噴射弁開弁・閉弁過渡期間において，針弁シート で閉塞が生じる条件になると，理論噴射率が気体 燃料噴射率計の実測噴射率をやや上回る．理論噴 射率算出の際，針弁シートでの流量係数を 1 とし て定式化を進めたため, 気体燃料噴射率計による 実測値とのずれを生じたと考えられる.

（5）開弁動作終了時，ならびに閉弁動作終了時におい て，気体燃料噴射率計の実測賁射率に「オーバー シュート」，「アンダーシュート」が見られる. 噴射并噴口と，気体然料噴射率計の計測管内径の 直径差が大きいため，噴射された気体が，計㵋管 内の流れ方向のみならず半径方向にも過度に膨張 することで生じる現象と推察される。気体然料噴 射率計の改善が必要であり, 今後の大きな課題で ある。

\section{謝辞}

本研究の実施に当たり, 元本田技術研究所 藤井 功 氏よりご協力を頂いた．本研究は，(独）科学技術振
興機構 JST サテライト新潟・平成 18 年度研究成果実 用化検討（FS）課題に採択され援助を頂いた。ここ に記して謝意を表する。

\section{文献}

(1) Matsuura, H. et al., Honda Dedicated CNG Passenger Vehicle, Proc. the 5th Intemational Conference and Exhibition on Natural Gas Vehicles(NGV 96), (1996), pp.1-8.

(2) Kikuchi, M. et al., Control of CNG DI Combustion by Fuel Jet, Proc. the 44th Symposium (Japanese) on Combustion, (2006), pp.300-301.

(3) Araki, $\mathrm{M}$ et al., Characteristics of CNG Direct Injection With Auto-Ignition, SAE Paper 2005-26-358.

(4) Hayashi, H., Bosch Type Injection Rate Meter, Intemal Combustion Engines, 7-12, (1968), pp. 58-64.

(5) Araki, M. et al., Injection Rate Measurements of a Gaseous Fuel Injector, Transactions of the Japan Society for Mechanical Engineers, 72-714, (2006), pp. 528-534.

(6) Araki, M. et al., Improvement of Injection Rate Measurement Accuracy of a Gaseous Fuel Injector, Transactions of the Japan Society for Mechanical Engineers, Under review.

(7) Matsuo, K., Compressible Fluid Dynamics, (1994), Rikogaku-sha, Tokyo, pp.75-77.

(8) Liepmann, H. W. and Roshko, A., Elements of Gasdynamics, (2000), Yoshioka Shoten, Kyoto, pp.50-51. 